\title{
Recent advances in understanding muscular dystrophy
}

\author{
K M D Bushby
}

The isolation of the causative genes in the muscular dystrophies, and from these the identification of the defective protein products, is at last giving an insight into the molecular basis of these conditions. These advances have come about through the techniques of reverse genetics, or positional cloning. ${ }^{1}$ All the muscular dystrophies have consistently eluded attempts to use standard biochemical techniques to identify the underlying defects in affected muscle. Most advances have been made in Duchenne and Becker muscular dystrophy, for which the gene and protein product have been known for some time. ${ }^{2}$ The gene for myotonic dystrophy has been isolated very recently, ${ }^{4-6}$ and linkage analysis has identified chromosomal localisations for facioscapulohumeral dystrophy on $4 q,{ }^{7}$ a form of recessive limbgirdle on $15 \mathrm{q},{ }^{8}$ a form of dominant limb-girdle on $5 q,{ }^{9}$ and Emergy-Dreifuss muscular dystrophy at Xq28. ${ }^{10}$

The gene involved in Duchenne and Becker muscular dystrophy is the largest yet identified, comprising over 2.5 megabases of genomic DNA with at least 75 exons and some very large introns. ${ }^{211}$ This encodes a 14 kilobases mRNA, from which a previously unknown muscle protein, dystrophin, is translated. The predicted molecular weight of dystrophin is approximately 427 kilodaltons and it comprises about $0.001 \%$ of total muscle protein. ${ }^{3}$ Dystrophin is also present in brain, where it uses a different promotor and exists as a different isoform. ${ }^{12} \mathrm{It}$ appears to be localised to neurons. ${ }^{13} \mathrm{~A}$ protein with significant homology to dystrophin encoded by a gene on chromosome 6 has also been described. ${ }^{14}$

Study of the sequence of dystrophin suggests the presence of four district domains. ${ }^{15}$ The Nterminal region has homology to $\alpha$-actinin and appears to have a site of interaction with F-actin. ${ }^{16}$ The second domain is thought to contain 24 or 25 triple helical repeats, ${ }^{17} 18$ which may confer elasticity on the molecule. ${ }^{17}$ There follows a sequence relatively rich in cysteine residues and a $\mathrm{C}$-terminus domain that is highly conserved between species. ${ }^{19}$ Dystrophin has been shown by electron microscopy to be located at the internal cytoplasmic face of the plasma membrane ${ }^{20}$ where it is associated with integral membrane glycoproteins ${ }^{21}$ via its Cterminus domain. The structure of this glycoprotein complex has recently been described and it has been shown that dystrophin deficient fibres also show a reduction in some components of this complex..$^{22} 23$ The structure and functional characteristics of the glycoprotein complex associated with dystrophin suggests that the function of dystrophin may be to link the sarcolemma membrane skeleton through a transmembrane complex to an extracellular glycoprotein which binds laminin. ${ }^{22}$ It has been shown that dystrophin deficient fibres are more sensitive to hypo-osmotic shock than controls, ${ }^{24}$ which supports the theory that dystrophin deficiency leads to mechanical weakening of the plasma membrane. An influx of calcium has been observed in dystrophin negative fibres, which may, directly or indirectly, stimulate protease activity, ${ }^{25}$ and myotubes negative for dystrophin have been shown to have abnormal calcium ion channels. ${ }^{26}$

It is now known that most mutations in the dystrophin gene are deletions, which can be identified in approximately $65 \%$ of patients with Duchenne muscular dystrophy and up to $85 \%$ in Becker muscular dystrophy. ${ }^{27} 28$ The high frequency of deletions and in particular the tendency for deletions to cluster in two particular regions of the gene has not yet fully been explained. ${ }^{29}{ }^{30}$ In those families where a patient has been shown to have a deletion DNA analysis offers a specific diagnostic test and a means of reliable and quick prenatal diagnosis. The demonstration of DNA abnormalities in patients without deletions is much more difficult in such a large gene, and only a handful of such mutations (point mutations and mutations in the promotor region) have been described. ${ }^{31} 32$ Techniques such as the use of dosage analysis for deletion detection in females, based on both Southern blotting and polymerase chain reaction (PCR) analysis, pulsed field gel electrophoresis, and most recently lymphocyte RNA PCR $^{33}$ have led to direct carrier detection being possible in some cases. However, in many cases carrier risk still has to be assessed as a probability calculation based on the results of creatine kinase testing and intragenic polymorphic markers. The high mutation rate in Duchenne muscular dystrophy has long been recognised, with approximately one third of cases estimated to result from a new mutation. The use of techniques that can directly detect a mutation in a boy and his mother has led to the recognition that germline mosaicism exists at a significant level in the Duchenne muscular dystrophy gene, with the risk of another affected son to a mother of an isolated case of Duchenne muscular dystrophy being around $20 \%$ with the at-risk 
haplotype even when a deletion has been identified in the boy and shown to be somatically absent in the mother. ${ }^{34}$

Dystrophin analysis, using antibodies to different parts of the dystrophin molecule, can be used both on muscle sections and western blots in diagnosis. Abnormalities of dystrophin seem to be specific to the Xp21 dystrophies, and so the finding of abnormal dystrophin can confirm the diagnosis even in the absence of a cDNA deletion. ${ }^{35} 36$ The use of a combination of genetic and dystrophin analyses to distinguish Becker muscular dystrophy accurately from the often clinically similar conditions of spinal muscular atrophy and limb-girdle muscular dystrophy has allowed the prevalence of this condition to be reassessed, and it has been shown to be much commoner than had previously been thought, ${ }^{37}$ the prevalence being similar to that of Duchenne muscular dystrophy and the cumulative birth incidence approximately one third. Some isolated cases of females with limb-girdle muscle weakness have been shown by dystrophin analysis to be manifesting carriers of dystrophin mutations ${ }^{38}$ a finding of great significance in counselling these women. Dystrophin abnormalities do not seem to be so easily detectable in female carriers without symptoms. ${ }^{39}$

Studies of the gene and protein abnormalities in large numbers of patients are beginning to unravel the complexity of the relationship between genotype and phenotype in the $\mathrm{Xp} 21$ dystrophies. A range of clinical severity, from the classical Duchenne muscular dystrophy patients at one end to the relatively mild Becker muscular dystrophy patients at the other, with patients of 'intermediate' severity between, is now known to exist as a result of different mutations in this gene. ${ }^{40}$ The ability to look directly for the molecular defect has also led to the recognition that severe muscle cramps may, at least for many years, be the only manifestation of Xp21 dystrophy. ${ }^{41}$ Occasional asymptomatic cases have been recognised with dystrophin gene deletions. ${ }^{42}$ The clinical range of severity is now known to be a reflection of a similar range of gene and protein defects. Deletions that disrupt the reading frame of the gene ${ }^{43}$ (with the expected result that no recognisable protein could be produced beyond the position of the mutation), are often associated with undetectable dystrophin, and these patients are generally very severely affected. However, dystrophin is detected in some patients with out of frame deletions, and the size of this dystrophin implies that the deletion behaves as if 'in frame', that is recognisable dystrophin is produced right through to the C-terminus of the protein, ${ }^{44} 45$ and the size of the protein is as predicted from the loss of the deleted exons.

Preliminary results suggest that the presence in muscle fibres of even a small amount of dystrophin may confer some functional advantage on these boys (LVB Nicholson, personal communication). At the other end of the clinical spectrum, patients with Becker muscular dystrophy are most commonly found to have deletions which do not disrupt the translational reading frame of the gene, so that a dystrophin molecule is produced which is internally deleted, but with both ends present and intact. Even very large deletions, providing they are in frame can be associated with a mild phenotype ${ }^{46}$ but it appears that deletions $45-47$ and $45-48$ of the dystrophin gene do tend to be associated with a relatively consistently mild clinical course. ${ }^{28}$ Across the range of Xp21 dystrophy, increasing abundance of dystrophin does seem to be associated with a milder clinical course, but there is no one value for abundance which reliably predicts a particular phenotype.

It is likely that alternative splicing mechanisms around deletions at the RNA level may be more widespread in the dystrophin gene than has yet been described, ${ }^{47}$ and this may account for apparent anomalies in phenotypegenotype correlations. Interactions with the dystrophin-associated glycoproteins or other genes may yet account for some of the unexplained variability in the dystrophin gene.

With an understanding of the molecular basis of the Xp21 dystrophies, work on possible therapeutic measures can now be more rationally planned and assessed. Animal models with dystrophin abnormalities have been identified. ${ }^{48}$ Myoblast transfer and gene therapy using a 'mini-gene' construct have both shown some promising results in animal work, ${ }^{50} 51$ and dystrophin transcripts have been identified in patients after myoblast transfer, ${ }^{52}$ but widespread use of either technique in patients is still generally held to be a long way off.

The mutation responsible for myotonic dystrophy has recently been described. ${ }^{4-6}$ There is variable amplification of a trinucleotide (CTG) repeat at the $3^{\prime}$ end of a gene, with an increase in the number of repeats associated with the disease phenotype. The number of repeats increases with the transmission of the mutation to successive generations. This mechanism explains the phenomenon of anticipation seen in families with myotonic dystrophy, where the severity of the disease is often seen to increase through successive generations. However, as amplification of the repeat may occur whether the mutation is passed through the male or female line, this mechanism is not enough alone to explain why congenital myotonic dystrophy is almost always maternally inherited. Women with myotonic dystrophy have around a $10 \%$ chance of having a child with congenital myotonic dystrophy, a risk which increases to $40 \%$ after the birth of one congenitally affected child, and which also rises with the severity of the disease in the mother. ${ }^{53}$

The gene has homology with genes encoding cyclic-AMP-dependent protein kinase, and its protein product has been designated myotonin protein kinase. $^{54}$ A 3 kilobase transcript is expressed at high levels in heart and lower levels in skeletal muscle and brain. ${ }^{55}$

Linkage analysis in the other muscular dystrophies should also ultimately lead to the identification of the genes and proteins involved, and no doubt to new ideas of how normal and abnormal genes and proteins interact in muscle. In the meantime, the work so far achieved has resulted in significant improvements in diagnosis and counselling for patients and their families. 
Many thanks to David Gardner-Medwin for helpful comments. $\mathrm{KMDB}$ is an MRC Training Fellow.

1 Orkin SH. Reverse genetics and human diseases. Cell 1986; 47:845-50.

2 Koenig M, Hoffman EP, Bertelson CJ, Monaco AP, Feener C, Kunkel LM. Complete cloning of the Duchenne muscular dystrophy (DMD) cDNA and preliminary genomic organisation of the DMD gene in normal and affected individuals. Cell 1987;50:509-17.

3 Hoffman EP, Brown RH Jr, Kunkel LM. Dystrophin: the protein product of the Duchenne muscular dystrophy protein product of the 1987;51:919-28.

4 Harley HG, Brook JD, Rundle SA, et al. Expansion of an unstable DNA region and phenotypic variation in myotonic unstable DNA region and phenotypic
dystrophy. Nature 1991;355:545-7.

5 Buxton J, Shelbourne P, Davies J, et al. Detection of an unstable fragment of DNA specific to individuals with
untention myotonic dystrophy. Nature 1992;355:547-8.

6 Aslandis C, Jansen G, Amemiya C, et al. Cloning of the essential myotonic dystrophy region and mapping of the putative defect. Nature 1992;355:548-51.

7 Wijmenga C, Frantz R, Brouwer OF, Moerer P, Weber JL, Padberg GW. Location of facioscapulo humeral muscular

8 Beckmann J, Richard I, Hillaire D, et al A gene for limbgirdle muscular dystrophy maps to chromosome 15 by linkage. Comptes Rendus de l'Academie des Sciences (Paris) 1991;312 series III: 141-8.

9 Speer MC, Yamaoka LH, Gilchrist JM, et al. Localisation of an autosomal dominant form of limb-girdle muscular dystrophy to chromosome 5q. Human genome mapping 11 , 1991: abstract 26929.

10 Romeo G, Roncuzzi L, Sangiorgi S, et al. Mapping of the Emery-Dreifuss gene through reconstruction of crossove points in two Italian pedigrees. Hum Genet 1988;80:59-62.

11 den Dunnen JT, Grootscholten PM, Bakker E, et al. Topography of the Duchenne muscular dystrophy (DMD) gene: FIGE and CDNA analysis of 194 cases reveals 115 deletion

12 Chelly J, Hamard G, Koulakoff A, Kaplan JC, Kahn A, Berwald-Netter $Y$. Dystrophin gene transcribed from different promoters in neuronal and glial cells. Nature 1990 344:64-5.

13 Lidov HGW, Byers TJ, Watkins SC, Kunkel LM. Localisation of dystrophin to post-synaptic regions of central nervous system cortical neurons. Nature 1990;348:725-8.

14 Love DR, Hill DF, Dickson G, et al. An autosomal transcript in skeletal muscle with homology to dystrophin. Nature 1989;339:55-7.

15 Koenig M, Monaco AP, Kunkel LM. The complete sequence of dystrophin predicts a rod-shaped cytoskeletal protein. of dystrophin predicis

16 Levine BA, Moir AJG, Patchell VB, Perry SV. The interaction of actin with dystrophin. FEBS Lett 1990;263:159-62.

17 Koenig M, Kunkel LM. Detailed analysis of the repeat domains of dystrophin reveals four potential hinge segments that may confer flexibility. F Biol Chem 1990;265:4560-6.

18 Cross RA, Stewart M, Kendrick-Jones J. Structural predic tions for the central domain of dystrophin. FEBS Let 1990;262:87-92.

19 Lemaire C, Heilig R, Mandel JL. The chicken dystrophin cDNA: striking conservation of the C-terminal coding and f $1988 ; 7: 4157-62$.

20 Cullen MJ, Walsh J, Nicholson LVB, Harris JB. Ultrastructural localisation of dystrophin in human muscle by using gold

21 Campbell KP, Kahl SD. Association of dystrophin and an integral membrane glycoprotein. Nature 1989;338:259-62.

22 Ibraghimov-Beskrovanaya $O$, Ervasti JM, Leveille CJ, Slaughter CA, Sernett SW, Campbell KP. Primary structure Slaughter CA, Sernett SW, Campbell KP. Primary structure of dystrophin-associated glycoprotein linking dystrop

23 Ervasti JM, Campbell KP. Membrane organisation of the dystrophin-guyloprotein complex. Cell 1991;66:1121-31.

24 Menke A, Jockuses $H$. Decreased osmotic stability of dystrophin less muscle cells from mdx mouse. Nature 1991 349:334-6.

25 Turner PR, Westwood T, Regan CM, Steinhardt RA Increased protein degradation results from elevated free calcium levels found in muscle from mdx mice. Nature 1988 ; 335:735-8.

26 Franco A, Lansman JB. Calcium entry through stretch inactivated ion channels in mdx myotubes. Nature 1990 344:670-3.

27 Koenig M, Beggs AH, Mayer M, et al. The molecular basis for Duchenne versus Becker dystrophy: correlation of 498-506.

28 Bushby KMD, Gardner-Medwin D, Nicholson LVB, et al. The clinical, genetic and dystrophin characteristics of Becker muscular dystrophy. 2: Correlation of phenotype with genetic and protein abnormalities. $\mathcal{F}$ Neurol (in press).
29 Blonden LAJ, Den Dunnen JT, Van Passen HMB, et al. High resolution deletion breakpoint mapping in the DMD gene by whole cosmid hybridisation. Nucleic Acids Res 1989;17:5611-21.

30 Love DR, England SB, Speer A, et al. Sequences of junction fragments in the deletion-prone region of the dystrophin gene. Genomics 1991;10:57-67.

31 Boyce FM, Beggs AH, Feener C, Kunkel LM. Dystrophin is transcribed in brain from a distant upstream promoter. Proc Natl Acad Sci USA 1991;88:1276-80.

32 Bulman DE, Gangopadhyay SB, Bebchuck KG, Worton RG, Ray PN. Point mutation in the human dystrophin gene: identification through western blot analysis. Genomics 1991;10:457-60.

33 Roberts RG, Bentley DR, Barby TFM, Manners E, Bobrow $M$. Direct diagnosis of carriers of Duchenne and Becker muscular dystrophy by amplification of lymphocyte RNA. muscular dystrophy by am $1990 ; 336: 1523-6$.

34 Van Essen AJ, Abbs S, Bouget M, et al. Parental origin and germline mosaicism of deletions and duplications of the
dystrophin gene. A European study. Hum Genet 1992;88: dystrophin

35 Hoffman EP, Fischbeck KH, Brown RH Jr, Johnson M, Medori R, Loike JD. Characterisation of dystrophin in muscle biopsy specimens from patients with Duchenne's or Becker's muscular dystrophy. $N$ Engl $\mathcal{F}$ Med 1988;318: 1368-8.

36 Nicholson LVB, Johnson MA, Gardner-Medwin D, Bhattacharya SS, Harris JB. Heterogeneity of dystrophin expression in patients with Duchenne and Becker muscular dystrophy. Acta Neuropathol (Berl) 1990;80:239-50.

37 Bushby KMD, Thambyayah M, Gardner-Medwin D. Prevalence and incidence of Becker muscular dystrophy. Lancet 1991;337:1022-4.

38 Arahata K, Ishihara T, Kamabura K, et al. Mosaic expressions of dystrophin in symptomatic cases of Duchenne's muscular dystrophy. $N$ Englf Med 1989;320:138-42.

39 Vainzof M, Pavanello RCM, Pavanello I, Tsanaclis AM, Levy JA, Passos-Bueno MR. Dystrophin immunoflurorescence pattern in manifesting and asymptomatic carriers of Duchenne's and Becker muscular dystrophies
ages. Neuromuscular Disorders 1991;1:177-83.

40 Bushby KMD. Genetic and clinical correlations of Xp21 dystrophy. $\dot{f}$ Inherited Metab Dis (in press).

41 Gospe SM, Lozano RP, Lava NS, Grootscholten BS, Scott MD, Fischbeck KH. Familial X-linked myalgia and cramps: a non progressive myopathy associated with a deletion in the dystrophin gene. Neurology 1989;39:1277-80. male with an inherited deletion of one exon within the DMD gene. Hum Genet 1990;84:207-9.

43 Monaco AP, Bertelson CJ, Liechti-Gallati S, Moser H, Kunkel LM. An explanation for the phenotypic differences between patients bearing partial deletions of the DMD locus. Genomics 1988;2:90-5.

44 Nicholson LVB, Johnson MA, Davison K, et al. Dystrophin or a 'related protein' in Duchenne muscular dystrophy? or a 'related protein' in Duchen
Acta Neurol Scand 1991 (in press).

45 Nicholson LVB, Bushby KMD, Johnson MA, Den Dunnen JT, Ginjaar IB, Van Ommen GJB. Predicted and observed sizes of dystrophin in some patients with deletions that sizes of dystrophin in some patients with deletions
disrupt the open reading frame. 7 Med Genet (in press).

46 Norman AM, Thomas NJT, Kingston HM, Harper PS Becker muscular dystrophy: correlation of deletion type with clinical severity. I Med Genet 1990;27:236-9.

47 Chelly J, Gilgenterantz H, Lambert M, Hamard G, Chafey P Recan D. The dystrophin transcripts in DMD and BMD patients with gene deletion. In: Angelini C, Danieli GA Fontanari D, eds. Muscular dystrophy research: from molecular diagnosis toward therapy. Amsterdam: Excerpta Medical International Congress Series 934, 1991:147-56.

48 Carpenter JL, Hoffman EP, Romanul FCA, et al. Feline muscular dystrophy with dystrophin deficiency. Am $\mathcal{J}$ Pathol 1989;135:909-19.

49 Sicinski P, Geng Y, Ryder-Cook AS, Bernard EA, Darlison MG, Barnard PJ. The molecular basis of muscular dystrophy in the MDX mouse-a point mutation. Science trophy in the MDx

50 Ascadi G, Dickson G, Love DR, et al. Human dystrophin expression in MDX mice after intra muscular injection of expression in MDX mice after intra muscul

51 Partridge TA. Invited review-myoblast transfer: a possible therapy for inherited myopathies? Muscle Nerve 1991;14: therapy for

52 Gussoni E, Pavlath GK, Lanctot AM, et al. Normal dystrophin transcripts detected in Duchenne muscular dystrophy patients after myoblast transplantation. Nature 1992;356:435-8.

53 Koch MC, Grimm T, Harley HG, Harper PS. Genetic risks for children of women with myotonic dystrophy. $A m \mathcal{J}$ Hum Genet 1991;48:1084-91

54 Mahadeven M, Tsilfiois C, Sabohrin L, et al. Myotonic untranslated region of the gene. Science 1992;255:1253-5.

55 Fuy-H, Pizzutti A, Fenwick RG Jr, et al. An unstable triple repeat in a gene related to myotonic muscular dystrophy. Science 1992;255:1256-8. 